\title{
Key Benefits of Adopting Lean Manufacturing Principles in Indian Construction Industry
}

\author{
Subhav Singh ${ }^{1,}$ Saurav Dixit ${ }^{2 *}$, Sanjay Sahai ${ }^{3}$, Ameet $\mathrm{Sao}^{2}$, Yogesh $\mathrm{Kalonia}^{2}$, and Raja Subramanya Kumar ${ }^{4}$ \\ ${ }^{1} \mathrm{~K}$ R Mangalam University, Gurgaon, India \\ ${ }^{2}$ RICS School of Built Environment, Amity University, Noida, India \\ ${ }^{3}$ Amity Business School, Amity University, Noida, India \\ ${ }^{4}$ Modulor, UAE
}

\begin{abstract}
Objectives of a lean production system (LPS) is to maximise value and minimise waste, by applying specific lean tools and techniques such as 5S, LPS, JIT, VSM, PULL, Kaizen, Six Sigma and many others techniques in a new production process. LPS is a philosophy based on the lean principles developed in Toyota by [1] [2] named as lean manufacturing principles and further developed as lean philosophy [3]. The main benefits of utilising $5 \mathrm{~S}$ are identified from the literature review and a structured questionnaire is prepared. The data is collected using convenient sampling technique from the professionals working in the industry. The collected data is analysed using different tools and techniques. A total of 9 benefits were identified from the literature review and the expert opinion from the industry. The findings of the study contribute to the existing body of knowledge and lay down few suggestions to the industry for implementing $5 \mathrm{~S}$ in the Indian context. The findings of the study conclude that the lean principles support the Indian manufacturing industry to improve productivity, quality, and reduction in cycle time The study is conducted using primary data collection and the sample size is small (86).
\end{abstract}

Keywords: Lean Production System; Waste Reduction; Productivity; 5S; and Indian Manufacturing Industry.

\section{Introduction}

Lean is tied in with accomplishing an adjusted utilization of individuals, materials and assets. This enables organizations to decrease costs, dispose of waste and convey extends on time and it isn't tied in with trimming everything deep down and crushing more out of what is left [7][2]. Lean development is the down to earth use of lean assembling standards, or lean reasoning, to the building condition [8], [9]Advantages of the new generation theory as far as efficiency, quality, and markers were sufficiently strong by and by with a specific end goal to improve the fast dissemination of the new standards [9]. The lean reasoning is tied in with: Getting work to stream dependably and typically on a development site requires the flawless arrangement of the whole production network in charge of built offices to such an extent that esteem is boosted and squander is limited. With such an expansive degree, any reasonable person would agree that apparatuses found in Lean Manufacturing and Lean Production, as honed by Toyota and others, have been adjusted to be utilized as a part of the satisfaction of Lean development standards. TQM, SPC, six-sigma, have all discovered their way into lean development. Also, devices and strategies found in different territories, for example, in sociology and business, are utilized where they are relevant. The instruments and techniques in development administration, for example, CPM and work breakdown structure, and so on. Are likewise used in lean development executions.

"One can consider lean development in a route like macroeconomics. Lean development draws upon the standards of venture level administration and upon the rule that administer generation level administration. Lean development perceives that any fruitful task undertaking will definitely include the communication amongst venture and generation administration [6].

- Sort - do we have all that we require, yet just those things we require, to achieve our assignment inside the site, the work zone or the workplace?

- Set - in what capacity should we best outline our work site or region with the goal that the zones, materials, apparatuses and gear are in the most secure, most proficient and best place. The visual administration is then used to set the work environment so an irregular condition is effectively observed - signposting, outline, shadow sheets, naming, least/most extreme levels,

Corresponding author: $\underline{\text { sdixit } @ \text {,ricssbe.edu.in }}$ 
numbering and shading coding all empower us to tell initially that we are set up for progress.

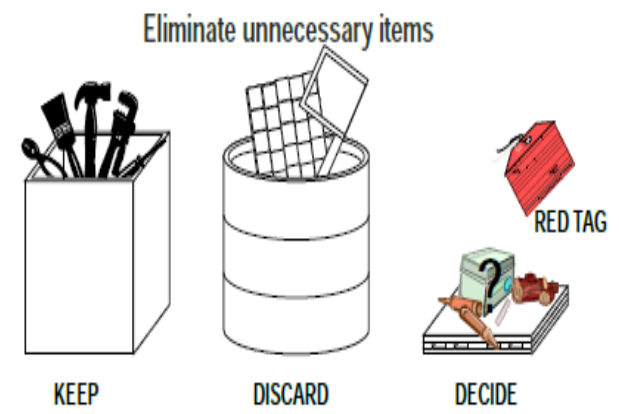

Fig 1 Sorting procedure

- Shine - conveying things to a spotless and clean condition and keeping the work environment in great request with the goal that it is prepared for utilize.

- Standardize - concurring between the groups the standard to which the work environment will be continued, shooting this and showing it so everybody is sure about how the function place should look.

- Sustain - the initiative work important to keep the initial 4Ss set up, crafted by examining and obvious authority in the work put.

\subsection{S benefits}

Worker learning and investment is the first advantage watched when $5 \mathrm{~S}$ is executed in the association [10]. 5S execution brings about better housekeeping and in this way better visual work environment is seen in the association [11][12]. 5S usage likewise guarantees more secure workplace [13]. The decrease in waste, time and cost is another great advantage of $5 \mathrm{~S}$ ([3], [14]. [15] found $5 \mathrm{~S}$ usage brings about enhanced quality, profitability and effectiveness.

To stay in the business field it is of highest critical to winning hearts of client however quality and cost of the item or administration. It is additionally vital to have a manageable creation with persistent change. The present need of the association is to convey top notch item through persistent change [1].However, fabricating association all through the world is under extraordinary strain to diminish the cost and address the difficulty of keeping up worldwide quality guidelines [2]. Lean Manufacturing is the psalm of survival and accomplishment of any association through limiting the wastage (Muda) of assets.

\section{Literature review}

[2] Considered the basic issues looking by small-scale businesses while offering their item. SSE (Small Scale Enterprise) isn't having enormous budgetary reinforcement and in this manner, they are relying on the income a great many contemplated the significance of small and medium scale ventures in an Indian setting. Medium size assembling industry assumes a vital part of Indian economy. Their commitment to the financial advancement of the country is without a doubt noteworthy. However, the profitability level of these businesses is very low when contrasted with another country [16] portrayed the execution and advantages of small-scale fabricating industry in India. Small-scale ventures frame a critical segment constituting $40 \%$ of the aggregate yield to the privet area and considerably more huge is the business age limit of small-scale sector.[17] Demonstrates the issue to support in the worldwide market for an association. Lean assembling is the song of survival and accomplishment of any association. The objective of lean assembling is to limit a wide range of waste so the cost of the item can be reduced. [18] depicted the improvement of key regions which could be utilized to survey the appropriation and usage of lean assembling practice likewise displayed a portion of the key territories created to assess and decrease the ideal undertaking in order to upgrade their generation proficiency. Concentrated on the usage of lean on the small maker of each of the 4-wheel drive vehicles, through execution of essential lean device, the small make quickly increment yield and diminish quality imperfections by $80 \%$. [19] Exhibited strategy for deciding the genuine issue related to businesses in the usage of lean. They likewise introduced determination of required lean instruments in the light of organization's long-haul vision. [20] portrayed the means attempted for the execution of $5 \mathrm{~S}$ stressing on the advantage of an association. Additionally depicted the start and advantage of actualizing the 5S. [7] Presents a persistent change system intending to enhance fabricating at auto Exhaust. The execution of $5 \mathrm{~S}$ has a prompt and huge impact on the arrangement of exercises in the work post, in this manner affecting the execution of the process in the dissected organization. [11] took a shot at the usage of $5 \mathrm{~S}$ on the plastic trim industry. $5 \mathrm{~S}$ is utilized as a part of the small industry and furthermore demonstrated the points of interest and advantages of 5S execution. [21] exhibited the approach for computation of every $S$ in the $5 \mathrm{~S}$ framework.

The 5S's are key lean ideas got from the Japanese words seiri (sort), seiton (set all together), seiso (sparkle), seiketsu (institutionalize) and shitsuke (sustain).2 Companies receiving the lean creation reasoning frequently execute the $5 \mathrm{~S}$ procedure to convey request to the working environment and bolster lean generation. One important part of the lean creation rationality is its accentuation on esteem.

\subsection{Why utilize $5 S$ ?}

The $5 \mathrm{~S}$ program is a demonstrated model for sorting out and keeping up a generation operation. It is frequently utilized as a part of assembling operations, specifically dynamic ones. The program additionally underpins the visual work environment. [2] Alluded to the 5Ss as "mainstays of the visual working environment" in the title of his book on $5 \mathrm{~S}$, in a $5 \mathrm{~S}$ domain there is a place for everything, and everything is in its place. Time spent looking for things is basically wiped out, and strange or missing things are quickly evident in a legitimately working $5 \mathrm{~S}$ office. The $5 \mathrm{~S}$ program plays out a comparative capacity for providing support. The clients 
of the framework immediately know where to discover data about their supply base, and absent or obsolete data is right away evident. To actualize a $5 \mathrm{~S}$ program for provider upkeep, you ought to maintain the following five rules.

The initial phase in actualizing $5 \mathrm{~S}$ for lean manufacturing is to take a voyage through the objective zone and check with red labels those things that show up strange or superfluous. After everything is looked into, it is either placed in its appropriate place or expelled in the event that it is superfluous or repetitive. The sort procedure is basic to organizing the workspace required for lean creation.

While applying the sort technique to the supply base, you select providers to add to the framework and eliminate from the framework. In acquiring language, this is known as supply base union or rationalization. Arranging the provider base through solidification: • Reduces the misuse of wasteful work strategies by

Many companies apply quality approaches such as lean manufacturing and six sigma methodologies to minimize defects and waste and to improve performance output. Lean manufacturing refers to a methodology designed to lower the costs involved in the production with a view to minimizing waste[22] Research has shown that companies that implement and practice lean manufacturing or lean production see a significant improvement in operational performance[5]. [23] State that six sigma is a statistical technique that permits a scientific evaluation of processes and transactions for the reduction of variability and the removal of defects. However, this paper investigates the status of performance outcomes of companies based on the methodology that has been implemented within the organizations. Results reveal applications in three different categories. Firstly, companies that implemented lean manufacturing only. Secondly, companies that use a combination of lean manufacturing and six sigma. Thirdly, particulars of limited tools of lean six sigma implemented, where they didn't refer to either lean manufacturing or six sigma with their organization.

However, the goals of this paper are to identify the powerful application that is helpful on increasing companies' performance and the effective industry that perform these lean manufacturing and $5 \mathrm{~S}$ practices across financial, operational and innovation performance. This paper investigates not only the impact of lean manufacturing and $5 \mathrm{~S}$ implementation but also the influence of the implementation method based on the type of industry.

\subsection{Benefits of adopting lean principles}

Table 1 benefits of implementing lean form literature review

\begin{tabular}{|l|l|}
\hline Author's & Benefits identified \\
\hline & $\begin{array}{l}\text { Reduction in lead time, reduction } \\
{[4],[7],[12],[22],}\end{array}$ in work in process (WIP), \\
{$[24]-[26],[27]$,} & reduction in Waste, continuous \\
{$[28]$} & improvement \\
\hline
\end{tabular}

\begin{tabular}{|c|l|}
\hline & $\begin{array}{l}\text { Reduction in operating cost, Late } \\
\text { delivery, and Space constraints, } \\
\text { Enhance productivity, space } \\
\text { utilization, and value for money }\end{array}$ \\
\hline$[11],[29]-[33]$ & $\begin{array}{l}\text { Inventory control, Customer } \\
\text { service, improves quality, }\end{array}$ \\
{$[2],[3],[5],[6]$,} & improved communication, and \\
{$[8],[9],[14],[20]$,} & reduce cycle time \\
{$[23],[34]-[42]$}
\end{tabular}

\section{Research Methodology}

For this research paper, a questionnaire survey method has been used to analyse the relative impact of $5 \mathrm{~S}$ on the identified issues in the Indian manufacturing industry. For this, the structured questionnaire survey is shared with the professionals, suppliers, customer, and consultants associated with the manufacturing industry. The received data were analyzed using Relative importance index (RII), RII was applied to prioritise the severity of the factors"[43].

Quantitative research methodology is adopted for the study. The data is collected using structured questionnaire survey. Primary data has been collected for the study because of non-availability of secondary data on the said title. The convenience sampling technique is used to collect the data from the known and easily approachable respondents. The questionnaire is shared with 350 professionals working in different segments of the economy including but not limited to manufacturing, production, suppliers, customers, transporters, logistics movers and other consultants working in the industry. A total of 86 valid responses were received with a response rate of $24.5 \%$.

The structured questionnaire is divided into three parts: the first portion has information about the topic and general study that is to be conducted, the second part is the questionnaire itself and the last portion consists the feedback and any suggestion for the study by the respondents. The respondents were asked to rate the questions on the Likert scale of 1-5 given against each question.

\subsection{Reliability analysis}

Dependability analysis is needed to check the consistency of the model after some time, and Cronbach's alpha test was the best way to check the reliability of the data collected through questionnaire [5]. The value of Cronbach's alpha for this study is 0.723 which is considered to be good for the study [10].

\subsection{Respondent's profile}




\section{PERCENTAGE}

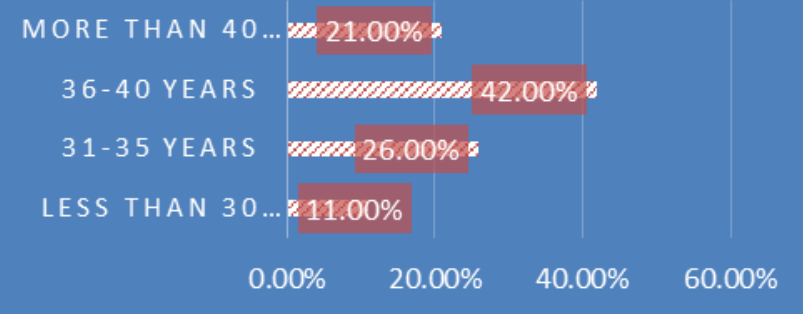

Fig 2 Respondents profile

\subsection{Relative importance index}

The received responses by the respondents were summarized in an Excel data sheet and the data analysed using SPSS software. Relative importance indices (RII) is performed to determine the benefits of using $5 \mathrm{~S}$ in the organizations and then followed by

Reliability analysis performed to check the consistency of the data received.

$$
\text { Rii }=\frac{\sum_{s=1}^{5} x^{*} n_{2}}{5 \mathrm{~N}}
$$

$\mathrm{r}$ is the rating on a Likert scale (1-5) as for the impact on construction efficiency for a specific element influencing construction profitability, $\mathrm{nr}$ is the number of respondents providing a specific Likert scale rating $\mathrm{r}, \mathrm{N}$ is the aggregate number of respondents to a specific question [6].

The value given to the Likert scale rating is as follows:
1. No effect
2. Less effect
3. Minor effect
4. Serious effect
5. Very serious effect

Table 2 ranking of attributes (RII)

\begin{tabular}{|l|l|l|l|l|}
\hline $\begin{array}{l}\text { Ran } \\
k\end{array}$ & $\begin{array}{l}\text { Total } \\
\text { respon } \\
\text { ses }\end{array}$ & $\begin{array}{l}\text { Total } \\
\text { score }\end{array}$ & RII & Attribute name \\
\hline 1 & 86 & 374 & $87.0 \%$ & $\begin{array}{l}\text { Enhance } \\
\text { productivity }\end{array}$ \\
\hline 2 & 86 & 361 & $84.0 \%$ & Improved quality \\
\hline 3 & 86 & 322 & $69.3 \%$ & $\begin{array}{l}\text { Reduction in cycle } \\
\text { time }\end{array}$ \\
\hline 4 & 86 & 314 & $69.1 \%$ & reduction in waste \\
\hline 5 & 86 & 297 & $68.6 \%$ & Reduction in WIP \\
\hline 6 & 86 & 283 & $68.4 \%$ & $\begin{array}{l}\text { Reduction in lead } \\
\text { time }\end{array}$ \\
\hline 7 & 86 & 266 & $67.5 \%$ & $\begin{array}{l}\text { Inventory } \\
\text { management }\end{array}$ \\
\hline 8 & 86 & 264 & $67.4 \%$ & Customer service \\
\hline 9 & 86 & 254 & $67.2 \%$ & $\begin{array}{l}\text { Better } \\
\text { utilization }\end{array}$ \\
\hline
\end{tabular}

\section{Discussion and conclusion}

The most significant benefits of adopting lean/5S
The top 3 most significant benefits of adopting lean $/ 5 \mathrm{~S}$ principles in the manufacturing industry are Enhance productivity, improved quality, and reduction in cycle time having a relative importance index value of $87 \%$, $84 \%$ and $69.3 \%$ respectively. These findings conclude that the lean $/ 5 \mathrm{~S}$ principle having a positive and significant impact in improving the baseline by supporting improvement in productivity, quality, reducing the overall cycle time of the product.

\subsection{Significant benefits of adopting lean/5S}

The three significant benefits of adopting lean/5S principles in the manufacturing industry are Reduction in waste, reduction in WIP, and reduction in lead time having a relative importance index value of $69.1 \%$, $68.6 \%$ and $68.4 \%$ respectively. These findings conclude that the lean $/ 5 \mathrm{~S}$ principle helps the manufacturing industry to sustain in long run by providing benefits such as reduction in waste, reduction in lead time, and reduction in WIP throughout the process.

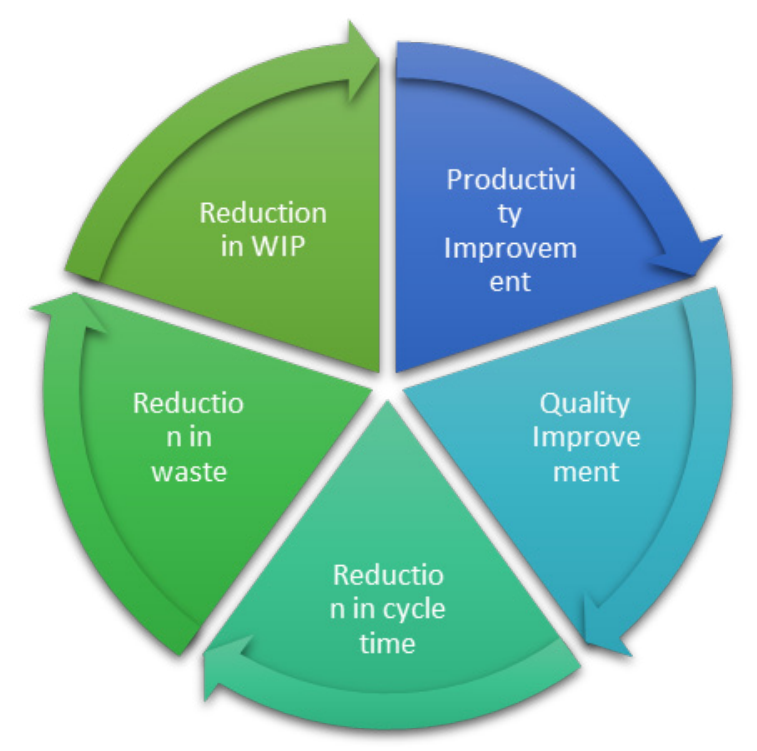

Fig 3 Key benefits of adopting lean manufacturing principles

The study provides an insight into the scope of lean tools/principles in Indian manufacturing industry by providing benefits mentioned as below. And secondly when you analysed the results of the RII the maximum value is $87 \%$ and the minimum is $67 \%$ i.e. the lean tools $/ 5 \mathrm{~S}$ principles are applicable to the main issue/problems identified from the literature review and provide an extra edge to the organisation implementing lean in their processes. This is observed that lean is more like a philosophy and an organisation can be able to adopt lean if and only it starts from the top management and should be applied as a philosophy at every stage of the product/service development. The main goal of lean is to create value and maintain the flow of the process. This study provides a better understanding $=\mathrm{g}$ of the lean 
tools and lean principles while highlighting the benefits of adopting lean/5S tools (figure).

\section{Limitations of the study}

This study is conducted by utilizing the collection of primary data to identify and analyse the benefits of lean $/ 5 \mathrm{~S}$ tools and principles in the Indian manufacturing industry. To validate the results and germanised the finding similar kind of study using a large data set is suggested. The author is currently working on the framework to improve the productivity of manufacturing industry by adopting the lean tools and principles.

\section{References}

[1] J. Mason, "Ean rimer," Readings, no. c, pp. 1-46.

[2] L. Koskela, G. Ballard, G. Howell, and I. Tommelein, Des. Constr. Build. Value, no. December 2015, pp. 211-226, 2002.

[3] J. Salvatierra-Garrido and C. Pasquire, J. Financ. Manag. Prop. Constr., vol. 16, no. 1, pp. 8-18, 2011.

[4] S. Mostafa, N. Chileshe, and T. Abdelhamid, Constr. Innov., vol. 16, no. 4, pp. 483-525, 2016.

[5] O. Ogunbiyi, J. S. Goulding, and A. Oladapo, Constr. Innov., vol. 14, no. 1, pp. 88-107, 2014.

[6] G. J. Sweis, M. Hiyassat, and F. F. Al-Hroub, Constr. Innov., vol. 16, no. 4, pp. 446-459, 2016.

[7] R. H. Ansah and S. Sorooshian, Sustain. Cities Soc., vol. 32, no. December 2016, pp. 348-356, 2017.

[8] A. H. A. Jamil and M. S. Fathi, Procedia Comput. Sci., vol. 100, pp. 634-643, 2016.

[9] M. A. Marhani, A. Jaapar, N. A. A. Bari, and M. Zawawi, Procedia - Soc. Behav. Sci., vol. 101, pp. 9099, 2013.

[10] A. Sao, S. Singh, S. Dixit, A. K. Pandey, and S. Singh, Int. J. Mech. Eng. Technol., vol. 8, no. 10, 2017.

[11] B. Jørgensen and S. Emmitt, Eng. Constr. Archit. Manag., vol. 15, no. 4, pp. 383-398, 2008.

[12] M. M. Carvalho and R. Rabechini, Int. J. Proj. Manag., vol. 35, no. 6, pp. 1120-1132, 2017.

[13] J. Meiling, F. Backlund, and H. Johnsson, Eng. Constr. Archit. Manag., vol. 19, no. 2, pp. 141-158, 2012.

[14] L. Zhang and X. Chen, Procedia Eng., vol. 145, pp. 1267-1274, 2016.

[15] M. L. Martens and M. M. Carvalho, "Key factors of sustainability in project management context: A survey exploring the project managers' perspective," Int. J. Proj. Manag., vol. 35, no. 6, pp. 1084-1102, 2017.

[16] L. A. Ocampo and E. E. Clark, t Asian Acad. Manag. J., vol. 20, no. 2, pp. 29-57, 2015.
[17] U. Dombrowski and T. Mielke, Procedia CIRP, vol. 17, pp. 565-570, 2014.

[18] L. M. Khodeir and R. Othman, Ain Shams Eng. J., 2016.

[19] B. Anvari, P. Angeloudis, and W. Y. Ochieng, Autom. Constr., vol. 71, no. Part 2, pp. 226-241, 2016.

[20] M. Ertürk, M. Tuerdi(Maimaitiaili. Tuerdi), and A. Wujiabudula, Procedia - Soc. Behav. Sci., vol. 229, pp. 444-452, 2016.

[21] P. Dallasega and E. Rauch, Sustainability, vol. 9, no. 10, p. $1888,2017$.

[22] C. Information, "W Orld a Cademy of S Cience, E Ngineering and T Echnology," p. 2017, 2017.

[23] X. Brioso, Procedia Eng., vol. 123, pp. 85-93, 2015.

[24] U. H. Issa, Alexandria Eng. J., vol. 52, no. 4, pp. 697-704, 2013.

[25] Engineers Australia WA Division, Eng. Aust., no. August, 2012.

[26] O. Ametepey, C. Aigbavboa, and K. Ansah, Procedia Manuf., vol. 3, no. Ahfe, pp. 1682-1689, 2015.

[27] S. Singh, A. Bala, S. Dixit, and D. Varshney, Int. J. Civ. Eng. Technol., vol. 9, no. 1, 2018.

[28] A. K. Pandey, S. Dixit, S. Bansal, S. Saproo, and S. N. Mandal, Int. J. Civ. Eng. Technol., vol. 8, no. 10, 2017.

[29] A. A. Al-Sudairi, Constr. Innov., vol. 7, no. 1, pp. 99-121, 2007.

[30] E. Lodgaard, J. A. Ingvaldsen, I. Gamme, and S. Aschehoug, Procedia CIRP, vol. 57, pp. 595-600, 2016.

[31] R. Jiang, C. Wu, C. Mao, and A. Shrestha, Procedia Eng., vol. 145, pp. 436-443, 2016.

[32] W. Aarseth, T. Ahola, K. Aaltonen, A. Økland, and B. Andersen, Int. J. Proj. Manag., vol. 35, no. 6, pp. 1071-1083, 2017.

[33] H. Bernstein and S. Jones, vol. 3, no. 2. 2010.

[34] R. F. Aziz and S. M. Hafez, Alexandria Eng. J., vol. 52, no. 4, pp. 679-695, 2013.

[35] A. Björnfot and Y. Sardén, Proc. 14th Int. Gr. Lean Constr., no. January, pp. 265-277, 2006.

[36] G. Ballard, I. Tommelein, L. Koskela, and G. Howell, Build. value, p. 504, 2002.

[37] J. Kilpatrick, Utah Manuf. Ext. Partnersh., pp. 1-5, 2003.

[38] U. Dombrowski and T. Mielke, Procedia CIRP, vol. 7, pp. 569-574, 2013.

[39] R. Pamfilie, A. J. P. (Draghici), and M. Draghici, Procedia - Soc. Behav. Sci., vol. 58, pp. 187-196, 2012.

[40] I. Alhuraish, C. Robledo, and A. Kobi, IFACPapersOnLine, vol. 49, no. 12, pp. 59-64, 2016. 
[41] G. A. Howell, Proc. Seventh Annu. Conf. Int. Gr. Lean Constr., pp. 1-10, 1999.

[42] T. da C., C. Milberg, and K. D. Walsh, Eng. Constr. Archit. Manag., vol. 19, no. 5, pp. 512-525, 2012.

[43] S. Dixit, S. N. Mandal, A. Sawhney, and S. Singh, Int. J. Civ. Eng. Technol., vol. 8, no. 8, 2017.

[44] S. Dixit, A. K. Pandey, S. N. Mandal, and S. Bansal, Int. J. Civ. Eng. Technol., vol. 8, no. 6, 2017.

[45] K. C. Iyer and K. N. Jha, Int. J. Proj. Manag., vol. 23, no. 4, pp. 283-295, May 2005. 